\title{
The blurred boundaries of ecological, sustainable, and agroecological intensification: a review
}

\author{
Alexander Wezel $^{1} \cdot$ Gizachew Soboksa $^{1} \cdot$ Shelby McClelland $^{1,2} \cdot$ Florian Delespesse $^{1}$. \\ Apolline Boissau ${ }^{1,3}$
}

Accepted: 23 July 2015 / Published online: 7 September 2015

(C) INRA and Springer-Verlag France 2015

\begin{abstract}
The projected human population of nine billion by 2050 has led to ever growing discussion of the need for increasing agricultural output to meet estimated food demands, while mitigating environmental costs. Many stakeholders in agricultural circles are calling for the intensification of agriculture to meet these demands. However, it is neither clear nor readily agreed upon what is meant by intensification. Here, we compare the three major uses, 'ecological intensification', 'sustainable intensification' and 'agroecological intensification', by analysing their various definitions, principles and practices, and also their historical appearance and evolution. We used data from the scientific literature, the grey literature, the websites of international organizations and the Scopus and FAOLEX databases. Our major findings are: (1) sustainable intensification is the most frequently used term so far. (2) The three concepts ecological intensification, sustainable intensification and agroecological intensification overlap in terms of definitions, principles and practices, thus creating some confusion in their meanings, interpretations and implications. Nevertheless, some differences exist. (3) Sustainable intensification is more widely used and represents in many cases a rather generalised category, into which most current farming practices can be put so long as sustainability is in some way addressed. However, despite its wider use, it remains imprecisely defined. (4) Ecological and agroecological intensification do introduce some major nuances and, in general, more
\end{abstract}

Alexander Wezel

awezel@isara.fr

1 Department of Agroecology and Environment, ISARA Lyon, 23 rue Jean Baldassini, 69364 Lyon cedex 07, France

2 Cornell University, Ithaca, NY, USA

3 EI Purpan, Toulouse, France explicitly stated definitions. For instance, ecological intensification emphasizes the understanding and intensification of biological and ecological processes and functions in agroecosystem. (5) The notion of agroecological intensification accentuates the system approach and integrates more cultural and social perspectives in its concept. (6) Even if some boundaries can be seen, confusion is still predominant in the use of these terms. These blurred boundaries currently contribute to the use of these terms for justifying many different kinds of practices and interventions. We suggest that greater precision in defining the terms and the respective practices proposed would indicate more clearly what authors or institutions are aiming at with the proposed intensification. In this sense, we provide new definitions for all three intensification concepts based on the earlier ones.

Keywords Agroecology · Agroecological intensification · Ecological intensification $\cdot$ Practices $\cdot$ Principles $\cdot$ Sustainable agriculture $\cdot$ Sustainable intensification

Contents

1. Introduction

2. Methods and Material

3. Ecological Intensification

3.1 Historical uses and definitions of ecological intensification

3.2 Principles of ecological intensification

3.3. Practices of ecological intensification

4. Sustainable Intensification

4.1. Historical uses and definitions of sustainable intensification

4.2. Principles of sustainable intensification

4.3. Practices of sustainable intensification

5. Agroecological Intensification 
5.1. Historical use and definitions of agroecological intensification

5.2. Principles of agroecological intensification

5.3. Practices of agroecological intensification

6. Discussion

6.1. Differences and blurred boundaries between the three intensification terms
6.1.1. Ecological versus sustainable intensification

6.1.2. Agroecological intensification versus ecological and sustainable intensification

6.2. Synthesis of definitions on the three concepts of intensification

6.3. Policy context and intensification

7. Conclusions

Acknowledgements

References

\section{Introduction}

In recent years, an increasing body of scientific literature on food security and agriculture introduce their research by offering a settled future: In 2050, there will be around nine billion humans to feed. These numbers combined with ongoing global climate change impacts, the depletion of natural resources and changes in diet due to an increase of economic livelihoods in developing countries are suggested to offer an almost insurmountable challenge for the world in producing enough food for all while taking care of the environment and social justice (Foley et al. 2011; Godfray et al. 2010).

In this perspective, many argue that business as usual is no longer possible because increasing production with current food systems will induce more environmental impacts, undermining the capacity of future generations to produce enough food (McIntyre et al. 2009). Others state that it is also important and possible to adapt within present farming systems, e.g. there is high potential to increase crop productivity in Africa (Tittonell and Giller 2013). In the same context, expanding agricultural land is only possible in a limited manner as farming is already putting pressure on natural areas and is an important factor in deforestation resulting in losses of biodiversity and increases in greenhouse gases emissions (Foley et al. 2005; Phalan et al. 2011).

To solve these issues, many stakeholders in food production are advocating for an 'intensification' of agriculture. The proposed solutions vary from radical food system changes to smaller field-focused improvements (e.g. Clay 2011; Foley et al. 2005; Royal Society London 2009) (Fig. 1). A variety of terms have emerged referring to general or more specific concepts and approaches to solve these issues. The present three major intensification concepts are 'ecological

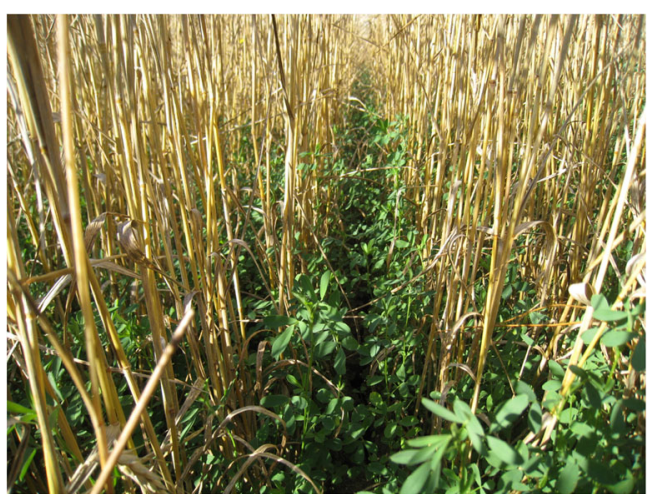

Fig. 1 Field-focused intensification: relay intercropping of wheat and undersown lucerne in south-eastern France. Lucerne is an interesting intercrop to be undersown in cereals for $\mathrm{N}$-fixation and providing increased soil cover for weed competition during cereal cropping and afterwards. It can also be harvested as forage because of its high fodder value (Photo A. Wezel)

intensification', 'sustainable intensification' and, more recently, 'agroecological intensification'. An important problem is that these concepts do not result out of a common consensus and remain poorly defined and understood globally (Petersen and Snapp 2015). Resulting from this lack of common definitions, some concepts have been misused or have become unclear in their practical implications (Garnett and Godfray 2012). Indeed, controversies have arisen on certain terms; some advocating that they will not bring enough changes to solve the existing problems, others that these are the only possible answers. When a debate is taking place with undefined terms, there is a high chance that the parties are referring to similar terms without understanding or acknowledging the difference in meanings they may each hold (Garnett and Godfray 2012).

In this paper, we focus on terms and concepts relevant to efforts to increase productivity while being sustainable or, in other terms, in concepts that advocate intensifying our current production models while reducing their environmental tradeoffs. We selected the three major intensification concepts presently used: ecological intensification, sustainable intensification, and agroecological intensification. The novelty of this paper is that these three concepts have not yet been analysed in a comparative analysis, taking all of them into account at once. In addition, the historical analysis of the first appearance of the terms and the evolution of the definitions used are also new. More specifically, the present paper aims at analysing the various uses of the three terms, their various definitions, underlying principles and practical implications. We then compare the narratives behind the three terms with each other to better understand the differences and commonalities they have. To complete this analysis, we discuss how these intensification terms are operationalized through agricultural practices and in which way these terms are already integrated in policies or laws. 


\section{Methods and material}

For this review, research on the different terms ecological intensification, sustainable intensification and agroecological intensification has been conducted in scientific literature as well as in grey literature. We searched back to the first year of appearance of the term as far as we could trace them back. We present an analysis from 1983 up to present. Websites connected to organizations making use of these terms were also used as other sources of information. A specific analysis was carried out on references from peer-reviewed scientific literature. The references have been selected out of the Scopus databases using the keywords ecological intensification, sustainable intensification and agroecological intensification or agro-ecological intensification in the title, abstract or keywords. The search tool Scopus was utilized to gather data about the frequency per year of use for each respective term in the title, abstract or keywords of scientific articles to analyse the temporal evolution of the use of the terms. In total, 241 scientific papers were found and analysed. To assess the pertinence of the articles for our qualitative analysis, we used several criteria: either (1) the existence of a definition of one of the terms, (2) the explanation of the practices involved with the specific use of the term or (3) the existence of explicit statements of general principles related to the term. In addition, we complemented our investigation with a historical analysis of appearance of the terms and the evolution of the definitions. However, for the qualitative analysis on definitions, practices and principles, only a reduced number of papers could be used as the majority of papers did not provide clear information on at least one of these three criteria.

Apart from the analysis of the academic literature, the authors also performed a Computer-Aided Text Analysis (CATA) of key policy documents searching the terms: Sustainable Intensification, Ecological Intensification and Agroecological Intensification. The CATA was carried out using NVivo (V. 10), one of the programs considered appropriate for such content analyses (Krippendorf 2004). CATA is particularly useful as it has been found to be more reliable and faster than human coders (Short et al. 2010). The goal of this analysis was to identify the use of terms related to intensification in international policy fora and within national legislations. In the international realm, all final reports of FAO Conference, FAO Council, FAO's Committee on Agriculture, FAO's Committee on World Food Security, all FAO Regional Conferences as well as ECOSOC Ministerial Declarations and General Assembly Resolutions with the words 'food' or 'agricult*' from 2000 until 2013 were searched to identify text containing the focal terms. This search was amended by searching the FAOLEX database, "a comprehensive and upto-date legislative database, one of the world's largest electronic collection of national laws and regulations on food, agriculture and renewable natural resources" (FAO 2014).

\section{Ecological intensification}

\subsection{Historical uses and definitions of ecological intensification}

The term ecological intensification was probably first used by Egger (1986) to describe a double approach which, on the one hand, uses all possible measures favouring soil fertility maintenance and, on the other hand, establishes the integration of crop and livestock production with forestry on the same parcel of land with the objective to have an agro-sylvo-pastoral system. A decade later, Cassman and Pingali (1995) mentioned the intensification of agriculture, but it is not until 1999 that Cassman (1999) stated that the goal of ecological intensification in agriculture is "further intensification of production systems that satisfy the anticipated increase in food demand while meeting acceptable standards of environmental quality". In the late 2000s, organizations and research centres worldwide started using and defining the term ecological intensification. In 2008, the French Agricultural Research Centre for International Development defined ecological intensification as agricultural systems "designed to use ecological processes and functions for different purposes, such as biological control, invasive species management, and efficient use of resources and ecological services" (CIRAD 2008). The Food and Agriculture Organization of the United Nations (FAO) in its Glossary on Organic Agriculture (FAO 2009) makes the first link to organic agriculture. In this document, ecological intensification and sustainable intensification are grouped under the same definition, "maximization of primary production per unit area without compromising the ability of the system to sustain its productive capacity" (FAO 2009).

As shown in Fig. 2, the use of the term ecological intensification in scientific publications appeared first in 1999, but not providing an explicit definition (Cassman 1999). The number of publication using this term increased more significantly from around 2010 onwards.

In recent years, the term ecological intensification seems to have evolved from a plot scale, agronomical approach with a focus on crop yields to a holistic and multi-disciplinary approach integrating concepts such as ecosystem services or biodiversity. Some authors (Doltra and Olesen 2013; Griffon 2013; Hochman et al. 2013) still use the initial definition of increasing food production while minimizing negative effects on the environment. Others (Brussaard et al. 2010; Doré et al. 2011; GRiSP 2013; Tittonell and Giller 2013) build on that definition and suggest an increase in resource-use efficiency, including reducing external inputs. Lastly, some authors have integrated the notion of ecosystem services in their definition. Doré et al. (2011) argue that ecological intensification should 'provide' ecosystem services, while Bommarco et al. (2012) and Tittonell and Giller (2013) suggest that ecological intensification should 'manage' ecosystem services in production 
Fig. 2 The use of the terms "ecological intensification", "sustainable intensification" and "agroecological intensification" in titles, abstracts and keywords of scientific publications listed in Scopus. Whereas the first use of one of the terms was in 1999, they have been more often employed since 2010. Sustainable intensification has increased enormously since 2011 and is today the most often used of these terms in scientific publications

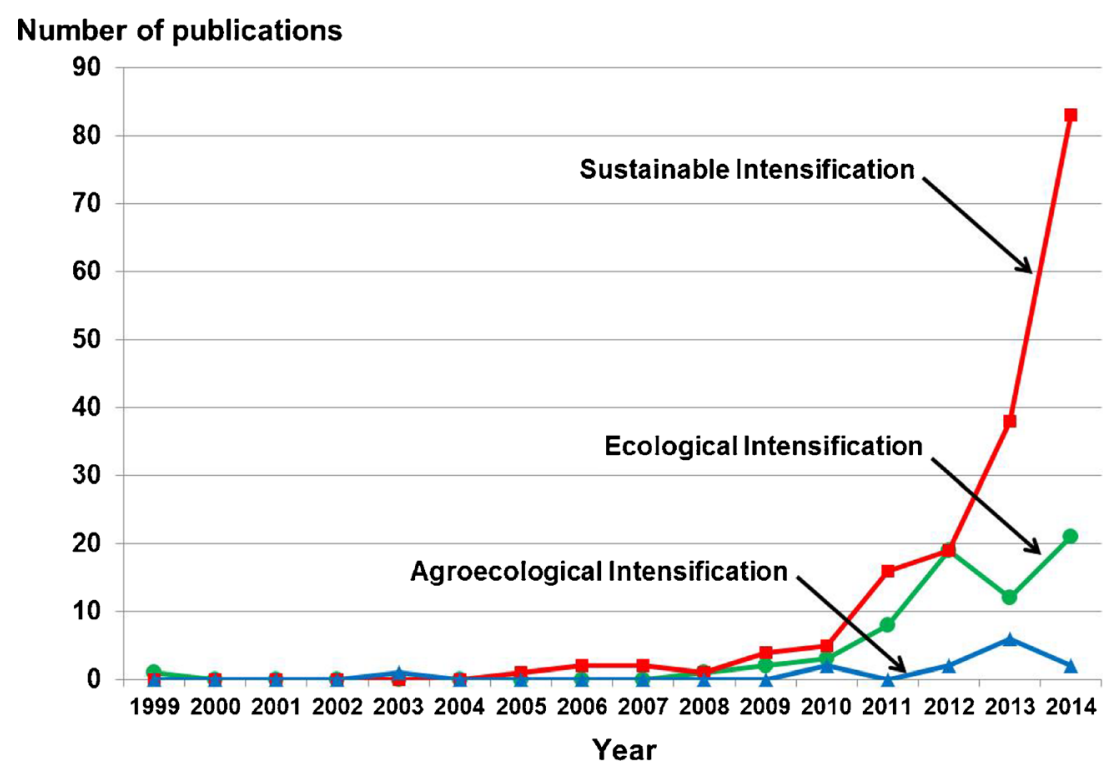

systems. Although not directly expressed in their definitions, Doré et al. (2011), Bommarco et al. (2012) and Tittonell and Giller (2013) integrate social aspects into ecological intensification. According to these authors, ecological intensification should also focus on human well-being and provide fiber, agro-fuels and food products, as well as environmental services. In a recent publication, Tittonell (2014) states that ecological intensification proposes landscape approaches that make smart use of natural functionalities that ecosystems offer. Here, the landscape approach mentioned provides a new dimension for the definition of ecological intensification. Gaba et al. (2014) support this in stating that to intensify ecological processes to increase beneficial biotic interactions, redefining farming systems with a holistic approach to agroecosystems and scaling up from plot to landscape scale is required.

In general, we see a historical evolution for the definitions on ecological intensification gradually integrating new aspects, e.g. ecosystem services and a landscape approach in more recent definitions. The major keywords used in the different definitions are shown in Fig. 3. To have more details about their use in definitions, we summarize this in Table 1 showing the key components of text used by different authors in their definitions. A comparison with the other intensification concepts will be provided and discussed under the discussion section.

\subsection{Principles of ecological intensification}

Principles of ecological intensification rely heavily on biological processes for management of soil fertility, resources and nutrients, biodiversity and interactions between organisms (plants, animals and soil organisms) (Agropolis 2013; Brussaard et al. 2010; CIRAD 2008; Egger 1986; FAO 2009). The aim is to intensify, make efficient use and develop a deep knowledge and understanding of these processes (Agropolis 2013; Bommarco et al. 2012; CIRAD 2008; Doltra and Olesen 2013; Doré et al. 2011). Many authors agree that developing in-depth knowledge of ecological processes is particularly important to develop expertise in this field. CIRAD (2008) targets not only the interactions between biotic and abiotic factors (i.e. bio-geochemical cycles and water cycles), but also plant and animal associations, the competition between them and their complementarities. Doré et al.

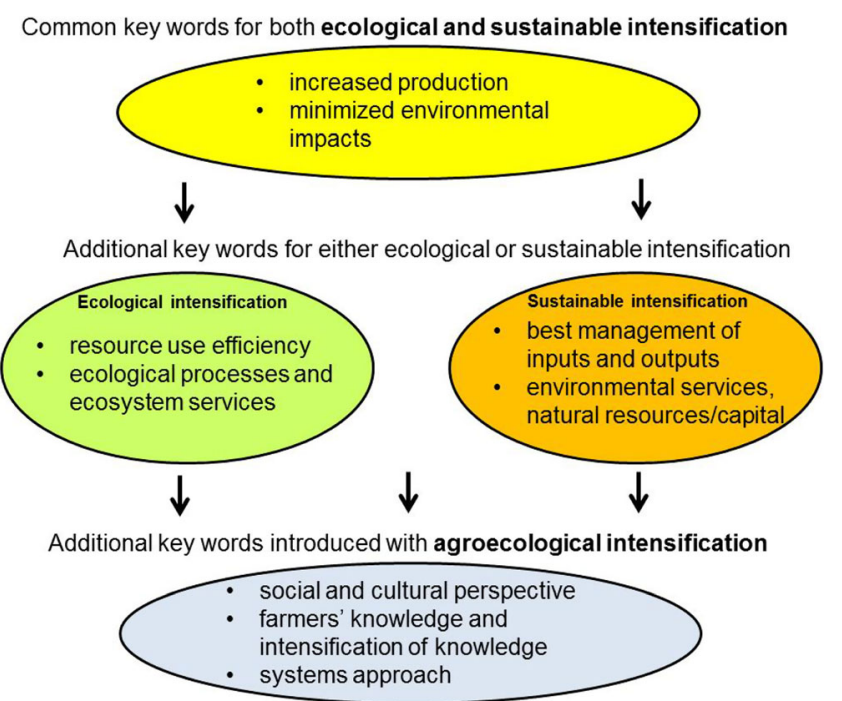

Fig. 3 Keywords used in definitions on ecological, sustainable and agroecological intensification. The top of the figure shows the common keywords for both ecological and sustainable intensification. The middle part adds other keywords which were either mentioned in publications for either ecological or sustainable intensification. The bottom part indicates which keywords were introduced in addition with agroecological intensification. Note: The keywords are summarized from a broad diversity of publications and might thus not always completely reflect the content of one specific publication on one of the intensification concepts 
Table 1 Summary of key components used in the major definitions of various authors for ecological, sustainable and agroecological intensification. In general, the key components in definitions for ecological intensification appear are found with different authors, whereas in definitions for sustainable and agroecological intensification they are often used only in one publication

Key components in definitions for the three intensification concepts

Ecological intensification

- Intensification of production systems of increasing food production while minimizing negative effects on the environment (Cassman 1999; Doltra and Olesen 2013; Griffon 2013; Hochman et al. 2013)

- Increase in use efficiencies of inputs and resources (CIRAD 2008; Brussaard et al. 2010; Doré et al. 2011; GRiSP 2013; Tittonell and Giller 2013)

- Systems using ecological processes and services (CIRAD 2008; Doré et al. 2011; Tittonell and Giller 2013; Tittonell 2014)

Sustainable intensification

- Substantial growth of yields while protecting or even regenerating natural resources (Pretty et al. 1996; Pretty 1997)

- Manipulation of inputs and outputs to increase productivity and/or production while maintaining the integrity of the system and the environment (Gibon et al. 1999)

- Increase in returns to land and labour and maintenance of soil nutrient balances (Ruben and Lee 2000)

- Intensification using natural, social and human capital assets, combined with the use of best available technologies and inputs that minimize harm to the environment (Pretty 2008)

- Producing more output from same area of land while reducing negative environmental impacts and increasing contributions to natural capital and flow of environmental services (Royal Society London 2009; FAO 2011; Pretty et al. 2011; Firbank et al. 2013)

Agroecological intensification

- Integration of ecological principles to reduce dependency on external inputs and increase the productive capacity of biotic and abiotic system components (Milder et al. 2012)

- Sustaining ecosystem services, while minimizing environmental costs and maintaining functional biodiversity through wildlifefriendly farming systems (Tscharntke et al. 2012)

- Improved performance through integration of ecological principles into farms and systems management (CCRP 2013)

- A set of improved inputs, implements, and practices that produce more output per unit of input whereby the use efficiency of those inputs is maximized (Vanlauwe et al. 2013a)

(2011) suggest improving knowledge of soil and plant sciences and the interactions between roots and micro- and macro-organisms. Bommarco et al. (2012) point out the need to understand the economic costs and benefits of biological processes and ecosystem services. CIRAD (2008) notes that "describing, explaining and exploiting the biodiversity of and the functions that regulate ecosystems" is of importance and along with other sources (Bommarco et al. 2012; CIRAD 2008; Doltra and Olesen 2013). Tittonell (2014) stresses that this will facilitate the efficient use of resources, functional biodiversity and ecosystem services.
Ecological intensification aims to achieve multiple goals: (i) biodiversity conservation (Brussaard et al. 2010), (ii) improved soil fertility management via the use of biodiversity and key symbioses that will facilitate nutrient recycling and balanced nutrient flows (Agropolis 2013; CIRAD 2008; FAO 2009), (iii) reduction of pest and disease infestations based on better understanding of the relations between organisms that will enable control and balance the number of parasites and predators in the ecosystems (Agropolis 2013; FAO 2009) and (iv) development of farming system resilience through diversified plant breeding adapted to environmental constraints such as climate change and water shortage (CIRAD 2008). On a higher level of analysis, further principles of ecological intensification in relation to food systems and human factors include decreased energy use, thus reducing greenhouse gas emission and dependence on fossil fuels (Cassman 2005; Doré et al. 2011), recycling of by-products or taking into account consumers' expectations of product quality (CIRAD 2008) and reduction in meat consumption and food losses and waste (Bommarco et al. 2012), reducing negative health and environmental externalities (Bommarco et al. 2012; Doré et al. 2011; Tittonell and Giller 2013) and increasing participatory involvement of stakeholders, building on local knowhow and knowledge in the introduction of new practices (Caron et al. 2014; CIRAD 2008) and collective decisionmaking (Tittonell 2014).

\subsection{Practices of ecological intensification}

The principles of ecological intensification are implemented through numerous tools and practices concerning cropping systems, soil, pest, nutrients and biodiversity management:

- Mixed cropping systems, diversified crop rotation, use of cover crops, direct-seeding and mulch-based cropping systems (Affholder et al. 2010; Agropolis 2013; Egger 1986; FAO 2009; Bommarco et al. 2012)

- Conservation tillage, minimizing soil compaction and soil detoxification (Agropolis 2013; Bommarco et al. 2012; Cassman 2005)

- Integrated pest management (Bommarco et al. 2012; Cassman 2005; CIRAD 2008)

- Improved fertilizer and nutrient management, regulation and monitoring of nutrient supply and fertigation (Agropolis 2013; Cassman 2005; CIRAD 2008; Egger 1986)

- Biodiversity preservation and promotion of positive allelopathic effects (Brussaard et al. 2010; CIRAD 2008).

To conclude, keywords used in the definitions on ecological intensification are 'increased production', 'minimized environmental impacts', 'resource use efficiency' and 'ecological processes and ecosystem services'. Principles of ecological 
intensification rely heavily on biological processes for management of soil fertility, resources and nutrients, biodiversity and interactions between organisms. These principles are translated into a broad variety of practices more commonly agreed by the majority of authors. Few additional more specific practices are mentioned by other authors.

\section{Sustainable intensification}

\subsection{Historical uses and definitions of sustainable intensification}

Sustainable intensification is emerging as the most frequently referenced new paradigm of agricultural production, and it is continuing to gain momentum in scientific and development literature (Pretty et al. 2011).

The usage and occurrence of the term sustainable intensification have increased in scientific publications since 2009 and very significantly since 2013 (Fig. 2). The term sustainable intensification can be traced back to a 1983 workshop report on sustainable intensification of tidal swamplands in Indonesia by the Research Group on Agro-ecosystems (KEPAS 1985). In the same year, the term was again used in a report produced for environmental assessment and management of coastal resources (Burbridge and Maragos 1985). In this report, the definition and principles of sustainable intensification are not stated explicitly, but the authors clearly foster the use of aquatic and associated natural resources, while at the same time proposing compatible multiple usages that do not compromise upcoming opportunities or diminish prevailing resources. Pretty et al. (1996) and Pretty (1997) first defined sustainable intensification as "substantial growth of yields in currently unimproved or degraded areas while at the same time protecting or even regenerating natural resources". Later, Gibon et al. (1999) reused this term with special reference to animal production as "the manipulation of inputs to, and outputs from, livestock production systems aimed at increasing productivity and/or production and/or changing product quality, while maintaining the long-term integrity of the system and its surrounding environment, so as to meet the needs of both present and future generations of humans". Ruben and Lee (2000) defined sustainable intensification from an agricultural economics standpoint with "the simultaneous increase in returns to land and labour (in the short run) and the maintenance of soil nutrient balances (in the long run)". The most cited and broadest definition of sustainable intensification, however, was provided by Pretty (2008): "Intensification using natural, social and human capital assets, combined with the use of best available technologies and inputs (best genotypes and best ecological management) that minimize or eliminate harm to the environment." A bit later, Royal Society London (2009) used the definition "increasing yields without adverse environmental impact and without the cultivation of more land." A more recent and widely cited definition of sustainable intensification comes from FAO's 2011 publication on Save and Grow, describing sustainable crop production intensification as "producing more from the same area of land while conserving resources, reducing negative impacts on the environment and enhancing natural capital and the flow of ecosystem services." Quite similar definitions were also used by Pretty et al. (2011) and Firbank et al. (2013).

In the last decade, sustainable intensification has gained worldwide recognition in many international policy, education and research organizations. Some of the notable international organizations that employ this term are the Food Climate Research Network in 2012, the Montpellier Panel in 2013, Food and Agriculture Organization of the United Nations (FAO 2011), United Nations General Assembly in 2010, Consultative Group on International Agricultural Research (CGIAR 2011), the International Fertilizer Industry Association (IFA 2013) and USAID (2013).

In the dialogue on the future of food production, various industries, environmental activists and farmers also employ the term sustainable intensification in their reports, conference speeches and magazines. Environmental movements seem to be more aware of this term, although its openness of definition - more an aspiration to increase yields without environmental damage - rather than a clear set of specific practices has led to some suspicion and criticism. One typical example of such critique is Friends of the Earth International's statement, "a wolf in sheep's clothing" in reference to the conventional agriculture industry's use of sustainable intensification (Collins and Chandrasekaran 2012). More about this discussion and debate can be found in the studies of Garnett and Godfray (2012), Kuyper and Struik (2014) and Tittonell (2014).

\subsection{Principles of sustainable intensification}

Given the current variety and controversy, over the usage of the term sustainable intensification, analysis and description of the fundamental principles and practices that underpin it is of great importance. Such an analysis helps to more clearly draw boundaries, also to the other types of intensification. However, although the sustainable intensification dialogue has been embraced by most international and national research and policy organizations as an aspiration, it has hardly ever been clearly limited to a specific set of principles and practices for its realization.

Different authors have presented different principles of sustainable intensification. Flavell (2010), Godfray et al. (2010), Pretty et al. (2011) and Firbank et al. (2013) have presented the principles of increases in production with as little additional land conversion as possible and increased use of renewable 
resources such as labour, light and knowledge. Other principles mentioned are to increase resource use efficiency and optimizing application of external inputs (Bos et al. 2013; Friedrich et al. 2012; Matson et al. 1997; McCune et al. 2011; Pretty 1997, 2008), to minimize direct negative environmental impacts of food production, to close yield gaps on underperforming existing agricultural lands (Bos et al. 2013; Garnett et al. 2013; Mueller et al. 2012) and to improve the utilization of crop varieties and livestock breeds (Carswell 1997; McCune et al. 2011; Pretty 2008; Ruben and Lee 2000). Moreover, objectives to change human diets, reduce food wastes (Bos et al. 2013; Garnett et al. 2013) and deliver productivity gains in ways that are socially acceptable (Garnett et al. 2013) are mentioned.

\subsection{Practices of sustainable intensification}

Agronomic and land management practices promoted with the term sustainable intensification are referenced in many publications reviewed. The most common practices that appeared with sustainable intensification can be summarized as follows:

- Conservation tillage (McCune et al. 2011; Reardon et al. 1999), improved crop rotations and applying living and residual mulches to cover the soil (FAO 2011; Matson et al. 1997)

- Use of legumes, cover crops and catch crops in rotations (Sumberg 2002; Tilman et al. 2011) and alley cropping (Pretty 1997; Raintree and Warner 1986)

- Integrated pest management (Pretty 1997; Pretty et al. 2011; Reardon et al. 1998)

- Soil conservation (FAO 2011; McCune et al. 2011).

More specifically mentioned are:

- Use of worm composts (McCune et al. 2011), on-farm mechanization (Friedrich et al. 2012), smarter, precision technologies for irrigation and nutrient use efficiency (FAO 2011), use of high yielding varieties including transgenic crops (Flavell 2010) and animal crop-integration (McCune et al. 2011)

To conclude, keywords used in the definitions on sustainable intensification are 'increased production', 'minimized environmental impacts', 'best management of inputs and outputs' and 'environmental services, natural resources/capital'. Principles of sustainable intensification remain often quite broad and diverse and are mostly less concrete than those of ecological intensification. The practices proposed are quite similar to the ones found for ecological intensification. Some single specific practices were also proposed by different authors.

\section{Agroecological intensification}

\subsection{Historical use and definitions of agroecological intensification}

Agroecological intensification is a relatively new term in the discourse of agricultural intensification. The growing importance of agroecology in the past decades and, in particular, since the 2000s (Gliessman 2007; Wezel and Soldat 2009; Wezel et al. 2009) might have contributed to this term's continually increasing use in literature, alongside a long history of practices and movements in Latin America (Altieri and Toledo 2011; Rosset and Martínez-Torres 2012; Wezel et al. 2009). An increased use in scientific literature can only be recognized since 2011 (e.g. CCRP 2013; Fonte et al. 2012; Haussmann 2011; Staver et al. 2013; Vanlauwe et al. 2013b). In general, the term is much less frequently used in scientific publications than sustainable intensification and ecological intensification (Fig. 2). The first use of the term is by Darkoh (2003), but does not provide any definition of the concept.

Several characterizations and definitions exist around the term agroecological intensification. Each definition includes different concepts of intensification as well as what constitutes intensification through agroecological principles. Milder et al. (2012) declare that "agroecological intensification integrates ecological principles into agricultural management to reduce dependency on external inputs and increase the productive capacity of biotic and abiotic system components". Tscharntke et al. (2012) state that "agroecological intensification sustains ecosystem services, while minimizing environmental costs and maintaining functional biodiversity" through wildlifefriendly farming systems. The Collaborative Crop Research Program (CCRP 2013) provides "improving the performance of agriculture through integration of ecological principles into farm and system management". Finally, Vanlauwe et al. (2013a) state it as "a set of improved inputs, implements, and practices that produce more output per unit of input relative to traditional practices and whereby the use efficiency of those inputs is maximised".

The issue with the definitions of agroecological intensification, however, lies not necessarily with the number of varying definitions but with the number of definitions that either directly quote understood definitions of ecological or sustainable intensification or cite papers promoting either of the two terms in the definition of agroecological intensification. Both Côte et al. (2010) and Haussmann (2011) link their definition to that of CIRAD $(2008,2013)$, and Dobermann and Nelson (2013) link their definition to Cassman (1999) with all original publications using the term ecological intensification. Similarly, Ochola et al. (2013) actually provide the sustainable intensification definition of FAO (2011) and Pretty et al. (2011) as the one they use for agroecological intensification. 


\subsection{Principles of agroecological intensification}

With regard to principles, Milder et al. 2012 state core principles as those cited in agroecology literature such as maintaining and enhancing soil health, improving recycling of biomass and nutrients, increasing biological diversity and beneficial interactions among species and optimizing use of water, energy, nutrients and genetic resources. CCRP (2013) provides a list of six characteristics of agroecological intensification: (i) optimizes local and global knowledge to improve efficiency and effectiveness of crop, soil and pest management; (ii) focuses on soil health and fertility and avoids pre- and post-harvest losses; (iii) is flexible and responsive to local conditions, including farmers' access to inputs and markets; (iv) requires deep and evolving understanding of biophysical, socio-economic, cultural, gender and other contexts, (v) reduces risk and increases productivity through resilience and adaptation and (vi) requires cross-sector and multilateral collaboration. Dobermann and Nelson (2013) define the following principles: "increased productivity and profitability, enhanced use of local resources, maximized returns from external inputs, improved stability and diversity of yields, reduced greenhouse gas emissions, enhanced ecological resilience, and environmental service provision." In all other instances where agroecological intensification is defined and principles are provided, these are based on citations of other authors which used them for describing ecological or sustainable intensification principles (e.g. Ochola et al. 2013).

\subsection{Practices of agroecological intensification}

Agroecological intensification practices build upon the above principles by giving more specific measures to be employed in designing agricultural systems. Many practices are mentioned by many authors:

- Mulching, intercropping, crop rotations, (Côte et al. 2010; Dobermann and Nelson 2013; Haussmann 2011; Karamura et al. 2013; Milder et al. 2012; Ochola et al. 2013) and integrated soil and nutrient management, including conservation agriculture (Dobermann and Nelson 2013)

- Soil and water conservation (Côte et al. 2010; Haussmann 2011; Karamura et al. 2013; Milder et al. 2012; Ochola et al. 2013)

- IPM and biological control strategies, (Côte et al. 2010; Dobermann and Nelson 2013; Haussmann 2011; Karamura et al. 2013; Milder et al. 2012; Ochola et al. 2013) and the judicious use of pesticides (Dobermann and Nelson 2013)

- Use of organic inputs (Côte et al. 2010; Dobermann and Nelson 2013; Haussmann 2011; Karamura et al. 2013;
Milder et al. 2012; Ochola et al. 2013) and balanced and more efficient use of fertilizers (Dobermann and Nelson 2013)

In addition, Dobermann and Nelson (2013) added: use of quality seed of a well-adapted high-yielding variety or hybrid; right time planting to maximize the attainable yield by capturing light, water and nutrients; enhance crop-tree-livestock interactions; maximized capture and efficient utilization of available water; and recycle and use of biomass and agricultural by-products. Many of these practices were also defined by Wezel et al. (2014) as agroecological practices, although they do not refer to agroecological intensification in their publication.

To conclude, the different definitions for agroecological intensification are mostly derived or taken from definitions of either ecological or sustainable intensification. Many of the principles mentioned are based on principles defined in agroecology. The practices proposed are generally similar to them found for ecological or sustainable intensification, but they seem to be in some cases more diverse and more specific.

\section{Discussion}

\subsection{Differences and blurred boundaries between the three intensification terms}

Definitions, principles and associated practices with the terms ecological, sustainable and agroecological intensification are sometimes confusing and overlapping, but some differences can be worked out. For this discussion, we use the major keywords used in the different definitions as a basis to show commonalities and difference for the three types of intensification (Fig. 3) and look also at their use in definitions (Table 1).

\subsubsection{Ecological versus sustainable intensification}

The keywords used in the different definitions on ecological intensification are 'increased production', 'minimized environmental impacts', 'resource use efficiency' and 'ecological processes and ecosystem services' (Fig. 3). How these keywords are used in the major definitions for ecological intensification is summarized in Table 1. In general, the key components in definitions for ecological intensification appear always with different authors, indicating a larger agreement among authors.

For the definitions of sustainable intensification, the same keywords increased production and minimized environmental impacts can be found as for ecological intensification. In contrast, resource use efficiency is stated less with sustainable intensification (only in FAO 2011), but mostly 'best 
management of inputs and outputs'. Also 'ecological processes and ecosystem services' is not present but the terms 'environmental services' or 'natural resources/capital' are used, except for FAO (2011) which uses the term 'ecosystem services'. In contrast to the key components provided in major definitions for ecological intensification, key components in definitions for sustainable intensification are often used only in one publication.

In general, regarding keywords and key components of definitions for ecological and sustainable intensification, a strong overlap for most definitions can be found even though the exact wording might differ. Nevertheless, the specific definitions among certain authors can vary by for example taking into account social aspects. Although it is not directly expressed in their definitions, Doré et al. (2011), Bommarco et al. (2012) and Tittonell and Giller (2013) integrate these social aspects into ecological intensification and Garnett et al. (2013) into sustainable intensification. Moreover, Kuyper and Struik (2014) and Struik et al. (2014) see in the co-existence of the terms ecological and sustainable intensification that similar words and shared language are used, but the discourse using the term can show very different worldviews.

Most definitions of ecological and sustainable intensification are primarily focused on productivity and environmental aspects, thus more oriented to field and farm scales. However, the more recent integration of social aspect mentioned before and also aspects such as human nutrition and food security, rural economies, sustainable development and sustainable value chain management (Garnett et al. 2013; van Bueren et al. 2014) enlarge this to the food systems scale. Tittonell (2014) states that ecological intensification proposes a landscape approach.

A large number of practices have been considered by the various authors to be part of both ecological or sustainable intensification. There remain, however, a few different opinions on certain key practices, for example whether to include transgenic crops into sustainable intensification (Flavell 2010; Petersen and Snapp 2015).

Another point is related to the way forward advocated for in the short term. Ecological intensification, as seen by some authors, puts a strong emphasis on the intensification of knowledge to better understand the many components of agroecosystems, particularly to enhance the cycles between the different biological, chemical and mineral components to achieve higher productivity. Achieving sustainability thus requires a strong effort to better understand agroecosystems and the role of scientists working with farmers is of primary importance (CIRAD 2008; Doré et al. 2011; Bommarco et al. 2012). The latter point was only also stressed by FAO (2011) for sustainable intensification and otherwise 'ecological literacy' has not been central to most descriptions of sustainable intensification.

A strong overlap for many definitions of ecological and sustainable intensification exist even though the exact wording might differ and specific definitions among certain authors can vary by for example taking into account social aspects.

\subsubsection{Agroecological intensification versus ecological and sustainable intensification}

Comparing agroecological intensification with ecological and sustainable intensification requires a more nuanced analysis. Many of the authors use existing definitions or concepts of ecological and sustainable intensification, but re-label them as agroecological intensification (Côte et al. 2010; Dobermann and Nelson 2013; Haussmann 2011; Karamura et al. 2013; Ochola et al. 2013). This understanding of ecological or sustainable intensification as agroecological intensification is problematic because it blurrs the boundaries between the three terms even more.

On the other hand, the principles for agroecological intensification clearly show a certain difference in terms of practical implications. The first is the insertion of the social and cultural perspectives into the definition of the principles of agroecological intensification (CCRP 2013). These perspectives are of great importance as most of the solutions advocated in ecological and sustainable intensification do not address these issues and mostly focus on the agronomic and environmental aspects and, to some extent, the economic ones. Agroecological intensification also distinguishes itself by emphasizing the importance of intensifying knowledge, not only for scientists and decision makers but for smallholders as well (Karamura et al. 2013). While social practices such as relying on local and cultural contexts and building on farmers knowledge are a part of agroecological intensification (Côte et al. 2010; CCRP 2013), proponents of sustainable or ecological intensification do not generally include these aspects as central to their concepts.

A second point is that agroecological intensification puts a stronger emphasis on having a systems approach (CCRP 2013; Dobermann and Nelson 2013). Most of the papers discussing the term refer to agricultural systems or agroecosystems and to analysing elements of these in a holistic perspective. This perspective requires taking into account the many and varied aspects of the systems to assess their interactive effects and leverage points toward (and away from) sustainability, including value chains and more globally food systems as well as knowledge systems. Although ecological intensification comprehends some of the fundamentals of systems thinking by integrating the notions of ecosystems, it is sometimes not clearly stated as a guiding principle by just focussing on implementing certain plot-scale practices for ecological intensification.

There are different ways in which agroecological intensification is operationalized, particularly among smallholders. For example, Dobermann and Nelson (2013) present 
interventions aimed at the short and long term. These interventions include closing yield gaps and reducing yield variability through enhanced breeding, using smart technologies for increased resource efficiency, investment in rural agricultural infrastructure and finding new business models for smallholder farming through collaboration with farmers. Such plans provide a useful means for presenting the goals of agroecological intensification as well as the ways in which proponents of the term can further modify and refine it. Systems of agroecological intensification are being assessed by rigorous comparisons to conventional farming systems (Karamura et al. 2013; Milder et al. 2012; Ochola et al. 2013) which can be helpful in providing an evidence base for their strengths, and criteria for success. Milder et al. (2012) introduced an assessment methodology that considers not just yields, but also the generation of ecosystem services. Both of these - the delineation of specific, time-bound action plans and assessments of outcomes - are two measures that from which initiatives for ecological intensification and sustainable intensification would also profit. This would allow for an improved understanding of the various concepts, their commonalities and differences.

To summarize, most definitions of ecological and sustainable intensification include the two main common key elements 'increased production' and 'minimized environmental impacts' and two additional ones each. Definitions of agroecological intensification re-use these key elements and add others such as 'social and cultural perspective', 'farmers' knowledge' and 'system approach'. Overall, many authors use definitions or concepts of ecological or sustainable intensification, but re-label them as agroecological intensification.

\subsection{Synthesis of definitions on the three concepts of intensification}

Based on the definitions of the different authors regarding the three intensification concepts, we tried to synthesis them for each of the concepts to provide new definitions which take into account the nuances between the concepts, even if they are sometimes not easy to detect from their definitions.

- Sustainable intensification: Producing more from the same area of land while conserving resources, reducing negative environmental impacts and enhancing natural capital and the flow of environmental services.

- Ecological intensification: Increasing food production while reducing the use of external inputs and minimizing negative effects on the environment by capitalising on ecological processes and ecosystem services from plot to landscape scale.

- Agroecological intensification: Improving the performance of agriculture while minimizing environmental impacts and reducing dependency on external inputs through integration of ecological principles into farm and system management.

\subsection{Policy context and intensification}

Building on the review of scientific literature, a review of relevant policy documents was also carried out. According to the FAOLEX database, none of the terms researched has been used - in English - in national legislations. Due to the level of attention these concepts have received both in academia and international policy-making, this is rather surprising.

Analysing the results from international policy documents, we found that only the most general of the three terms, sustainable intensification has been used and it has been found only in documents from FAO from 2004 to 2013: 2004: 1, 2008: 1, 2009: 2, 2010: 4, 2011: 1, 2012: 13, 2013: 4.

None of the documents examined provides a definition of Sustainable Intensification. Given the ambiguity of the term, this makes it difficult to actually move toward implementation of the international policy recommendations. In this context, however, it has to be said that FAO has indeed defined the term Sustainable Crop Production Intensification in its own work (FAO 2011). Nonetheless, it should be noted here that the lack of specificity within international policy documents might hinder national level implementation, also as none of the terms has been used in national level policy-making. Just as in the case of scientists, policy-makers must be clear in what they mean with sustainable intensification or resort to using better defined terms when a specific realm of practices and policies are intended.

\section{Conclusions}

This first comparative analysis on ecological, sustainable and agroecological intensification shows that the three concepts are overlapping to some extent and thus are a significant source of confusion. However, we have also found that some differences. Sustainable intensification is more widely used (see also Tittonell 2014; Petersen and Snapp 2015) and represents, in many cases, a rather generalised category into which most current farming practices can be put so long as sustainability is in some way addressed. Ecological and agroecological intensification do bring some major nuances and, in general, more explicitly stated definitions. For example, the notion of ecological intensification emphasizes the understanding and intensification of biological and ecological processes and functions in agroecosystem, and it also extends the scope to the landscape using and providing ecosystem services. Furthermore, the notion of agroecological intensification accentuates a systemic approach and integrates more clearly the cultural and social perspective in its concept.

Nevertheless, as the confusion between the terms is still predominant, we urge advocates of specific terms to explicitly state to which definition they are referring to and what are the underlying practices. Terms comprehending words such as 
sustainable, ecological or agroecological can be used too easily in exchangeable ways. As such, it is often not clear which farming practices apply to which terms. In a similar manner, an analysis of a select number of available international policy documents indicates that only the term sustainable intensification has been used in the last ten years, without ever having been defined in these policy documents.

This paper raises two critiques of the current use made of these terms. The first one is that most of the authors, in particular for sustainable intensification, are describing aspirational goals rather than practical guides toward sustainability. As a consequence, practical action plans or guidelines for farmers and policy makers are often missing or voluntarily kept vague. The second criticism concerns that intensification of agriculture focuses almost exclusively on increasing food production as the only possible answer to existing challenges. By doing so, advocates concentrate solely on a specific part of the food system rather than analysing its entirety, from the production to the consumption. In definitions, principles and practices of all the terms considered here, there should be a more explicit recognition that when production systems are managed with an ecosystem approach, they can generate not just goods (e.g. food and timber) but also multiple benefits including a diversity of ecosystem services such as water supply and purification, buffering of floods and droughts, air quality, energy, conservation of biodiversity as well as cultural and educational values. Equally, improving other elements of the food system, such as reducing food losses and food waste (Gustavsson et al. 2011), could reduce the pressure to which agriculture is subjected. Many stakeholders advocate an integrated approach to current and future challenges, including changing diets combined with agricultural intensification and reduce food losses and food waste (Foley et al. 2011).

Acknowledgments We are very grateful to Barbara Gemmill-Herren and Benjamin E. Graeub from the FAO, Rome, Italy, for their help in preparing this paper and comments and corrections on the manuscript.

\section{References}

Affholder F, Jourdain D, Quang DD, Tuong TP, Morize M, Ricome A (2010) Constraints to farmers' adoption of direct-seeding mulchbased cropping systems: a farm scale modelling approach applied to the mountainous slopes of Vietnam. Agric Syst 103:51-62. doi: 10.1016/j.agsy.2009.09.001

Agropolis, 2013. DMC - an ecological intensification engineering tool. www.agropolis.org/agronomy/research.php?id=10. Accessed 2 Oct 2013

Altieri MA, Toledo VM (2011) The agroecological revolution in Latin America: rescuing nature, ensuring food sovereignty and empowering peasants. J Peasant Stud 38(3):587-612. doi:10.1080/ 03066150.2011.582947

Bommarco R, Kleijn D, Potts SG (2012) Ecological intensification: harnessing ecosystem services for food security. Trends Ecol Evol 28(4):230-238. doi:10.1016/j.tree.2012.10.012
Bos JF, Smit ABL, Schröder JJ (2013) Is agricultural intensification in The Netherlands running up to its limits? NJAS Wagening J Life Sci 66:65-73

Brussaard L, Caron P, Campbell B, Lipper L, Mainka S, Rabbinge R, Babin D, Pulleman M (2010) Reconciling biodiversity conservation and food security: scientific challenges for a new agriculture. Curr Opin Environ Sustain 2(1-2):34-42. doi:10.1016/j.cosust.2010.03.007

Burbridge PW, Maragos JE (1985) Coastal resources management and environmental assessment needs for aquatic resources development in Indonesia. International Institute for Environment and Development, Washington DC, $\mathbf{1 2 9} \mathbf{p}$

Caron P, Biénabe E, Hainzelin E (2014) Making transition towards ecological intensification of agriculture a reality: the gaps in and the role of scientific knowledge. Curr Opin Environ Sustain 8:44-52. doi:10. 1016/j.cosust.2014.08.004

Carswell G (1997) Agricultural intensification and rural sustainable livelihoods: a 'think piece'. Institute of Development Studies, Brighton

Cassman KG (1999) Ecological intensification of cereal production systems: yield potential, soil quality, and precision agriculture. Proc Natl Acad Sci 96(11):5952-5959

Cassman KG (2005) Ecological intensification of agriculture and implications for improved water and nutrient management. In: Imas P, Price R (eds) Fertigation: optimizing the utilization of water and nutrients. International Symposium on Fertigation, Beijing, China, 20-24 September 2005. International Potash Institute, Horgen, Switzerland, pp 23-34

Cassman KG, Pingali PL (1995) Intensification of irrigated rice systems: learning from the past to meet future challenges. GeoJournal 35(3): 299-305. doi:10.1007/BF00989137

CGIAR (2011) CGIAR research program on integrated systems for the humid tropics. http://www.cgiar.org/our-research/cgiar-researchprograms/cgiar-research-program-on-integrated-systems-humidtropics/. Accessed 23 Sept 2014

CIRAD (Centre de coopération internationale en recherche agronomique pour le développement) (2008) CIRAD Strategic Vision 20082012. www.cirad.fr/en/content/download/970/31343/version/6/file/ CIRAD_Strategie_GB_web.pdf. Accessed 3 Oct 2013

CIRAD (Centre de coopération internationale en recherche agronomique pour le développement) (2013) Ecological intensification. www. cirad.fr/en/research-operations/priority-lines-of-research/ecologicalintensification/research-issues. Accessed 3 Oct 2013

Clay J (2011) Freeze the footprint of food. Nature 475:287-289. doi:10. $1038 / 475287 \mathrm{a}$

Collins ED, Chandrasekaran K (2012) A Wolf in Sheep's Clothing? An analysis of the 'sustainable intensification' of agriculture. Friends of the Earth International, Amsterdam

Côte FX, Tomekpe K, Staver C, Depigny S, Lescot T, Markham R (2010) Agro-ecological intensification in banana and plantain (Musa spp.): an approach to develop more sustainable cropping systems for both smallholder farmers and large-scale commercial producers. Acta Horticult (ISHS) 879:457-463

CCRP (Collaborative Crop Research Program) (2013) Agroecological intensification. McKnight Foundation, www.ccrp.org/programessentials/how-we-work. Accessed 2 Oct 2013

Darkoh MBK (2003) Regional perspectives on agriculture and biodiversity in the drylands of Africa. J Arid Environ 54(2):261-279. doi:10. 1006/jare.2002.1089

Dobermann A, Nelson R (2013) Opportunities and solutions for sustainable food production, background research paper. High-Level Panel of Eminent Persons on the Post-2015 Development Agenda. www. post2015hlp.org/wp-content/uploads/2013/05/Doberman-Nelson Solutions-for-Sustainable-Food-Production.pdf. Accessed $\overline{4}$ Nov 2013

Doltra J, Olesen JE (2013) The role of catch crops in the ecological intensification of spring cereals in organic farming under Nordic climate. Eur J Agron 44:98-108. doi:10.1016/j.eja.2012.03.006 
Doré T, Makowski D, Malézieux E, Munier-Jolain N, Tchamitchian M, Tittonell P (2011) Facing up to the paradigm of ecological intensification in agronomy: revisiting methods, concepts and knowledge. Eur J Agron 34:197-210. doi:10.1016/j.eja.2011.02.006

Egger K (1986) L'intensification écologique. Conservation (LAE) et amélioration des sols tropicaux par les systèmes agro-sylvopastoraux. In: Département Systèmes Agraires du CIRAD (ed) Aménagement hydro-agricoles et systèmes de production. Collection Documents Systèmes Agraires 6:129-135

FAO (2009) Organic agriculture: glossary on organic agriculture. FAO, Rome, pp 1-173

FAO (2011) Save and Grow. A policymaker's guide to the sustainable intensification of smallholder crop production. FAO, Rome, $102 \mathbf{p}$

FAO (2014) FAOLEX database: legislative database of national laws and regulations on food, agriculture and renewable natural resources. FAO, Rome

Firbank LG, Elliott J, Drake B, Cao Y, Gooday R (2013) Evidence of sustainable intensification among British farms. Agric Ecosyst Environ 173:58-65. doi:10.1016/j.agee.2013.04.010

Flavell R (2010) Knowledge and technologies for sustainable intensification of food production. New Biotechnol 27(5):505-516

Foley JA, DeFries R, Asner GP, Barford C, Bonan G, Carpenter SR, Chapin FT, Coe MT, Daily GC, Gibbs HK, Helkowski JH, Holloway T, Howard EA, Kucharik CJ, Monfreda C, Patz JA, Prentice IC, Ramankutty N, Snyder PK (2005) Global consequences of land use. Science 309(5734):570-574. doi:10.1126/science. 1111772

Foley JA, Ramankutty N, Brauman KA, Cassidy ES, Gerber JS, Johnston M, Mueller ND, O'Connell C, Ray DK, West PC, Balzer C, Bennett EM, Carpenter SR, Hill J, Monfreda C, Polasky S, Rockström J, Sheehan J, Siebert S, Tilman D, Zaks DP (2011) Solutions for a cultivated planet. Nature 478:337-342. doi:10.1038/nature10452

Fonte SJ, Vanek SJ, Oyarzun P, Parsa S, Quintero DC, Rao IM, Lavelle P (2012) Pathways to agroecological intensification of soil fertility management by smallholder farmers in the Andean highlands. Adv Agron 116:125-184

Friedrich T, Kienzle J, Kassam A (2012) A new paradigm for sustainable intensification and its implications for agricultural mechanization. In: CIGR-EurAgEng (ed) Rural Development. International Conference of Agricultural Engineering, Valencia, p P-0416

Gaba S, Bretagnolle, Rigaud T, Philippot L (2014) Managing biotic interactions for ecological intensification of agroecosystems. Front Ecol Evol 6/2014, doi:10.3389/fevo.2014.00029

Garnett T, Godfray C (2012) Sustainable intensification in agriculture, navigating a course through competing food system priorities. Food Climate Research Network and the Oxford Martin Programme on the Future of Food, University of Oxford, UK

Garnett T, Appleby MC, Balmford A, Bateman IJ, Benton TG, Bloomer P, Burlingame B, Dawkins M, Dolan L, Fraser D, Herrero M, Hoffmann I, Smith P, Thornton PK, Toulmin C, Vermeulen SJ, Godfray HCJ (2013) Sustainable intensification in agriculture: premises and policies. Science 341(6141):33-34. doi:10.1126/science. 1234485

Gibon A, Sibbald AR, Flamant JC, Lhoste P, Revilla R, Rubino R, Sørensen JT (1999) Livestock farming systems research in Europe and its potential contribution for managing towards sustainability in livestock farming. Livest Prod Sci 61(2-3):121-137

Gliessman SR (2007) Agroecology: the ecology of sustainable food systems. CRC Press, Boca Raton

Global Rice Science Partnership (GRiSP) (2013) Theme 3: ecological and sustainable management of rice-based production systems. http://grisp.irri.org/theme-3. Accessed 3 Oct 2013

Godfray HCJ, Beddington JR, Crute IR, Haddad L, Lawrence D, Muir JF, Pretty J, Robinson S, Thomas SM, Toulmin C (2010) Food security: the challenge of feeding 9 billion people. Science 327(5967):812818. doi:10.1126/science. 1185383
Griffon M (2013) Qu'est-ce que l'agriculture écologiquement intensive? Edition Quae, Versailles, France, $220 \mathrm{p}$

Gustavsson J, Cederberg C, Sonesson U, Van Otterdijk R, Meybeck A (2011) Global food losses and food waste. FAO, Rome

Haussmann B (2011) How CCRP could support the agro-ecological intensification (AEI) of the Sahel. http://ccrpaeix.drupalgardens.com/ sites/ccrpaeix.drupalgardens.com/files/hausssman_ccrp_aei.pdf. Accessed 26 Oct 2013

Hochman Z, Carberry PS, Robertson MJ, Gaydon DS, Bell LW, McIntosh PC (2013) Prospects for ecological intensification of Australian agriculture. Eur J Agron 44:109-123. doi:10.1016/j.eja. 2011.11.003

International Fertilizer Industry Association (IFA) (2013) 2012 Annual report. Report of the council of the 85th year to be presented to the annual general meeting on 22 May 2013

Karamura EB, Jogo W, Rietveld A, Ochola D, Staver C, Tinzaara W, Karamura DA, Kubiriba J, Weise S (2013) Effectiveness of agroecological intensification practices in managing pests in smallholder banana systems in East and Central Africa. Acta Horticult (ISHS) 986:109-126

KEPAS (Kelompok Penelitian Agro-ekosistem - Research Group on Agro-ecosystems) (ed) (1985) Tidal swamp agro-ecosystems of southern Kalimantan. Workshop report on Sustainable intensification of tidal swamplands in Indonesia held at Banjarmasin, South Kalimantan, July 18-24, 1983, Agency for Agricultural Research and Development, Jakarta, Indonesia, $146 \mathrm{p}$

Krippendorf K (2004) Content analysis: an introduction to its methodology. Sage, Thousand Oaks

Kuyper TW, Struik PC (2014) Epilogue: global food security, rhetoric, and the sustainable intensification debate. Curr Opin Environ Sustain 8:71-79. doi:10.1016/j.cosust.2014.09.004

Matson PA, Parton WJ, Power AG, Swift MJ (1997) Agricultural intensification and ecosystem properties. Science 277(5325):504-509. doi:10.1126/science.277.5325.504

McCune NM, González YR, Alcántara EA, Martínez OF, Fundora CO, Arzola NC, Cairo PC, D’Haesse M, DeNeve S, Hernández FG (2011) Global questions, local answers: soil management and sustainable intensification in diverse socioeconomic contexts of Cuba. J Sustain Agric 35(6):650-670. doi:10.1080/10440046.2011.586595

McIntyre BC, Herren HR, Wakhungu J, Watson RT (eds) (2009) Agriculture at a crossroads. IAASTD International Assessment of Agricultural Knowledge, Science and Technology for Development: Global Report. Island Press, Washington DC. USA, 590 p. http:// www.fao.org/fileadmin/templates/est/Investment/Agriculture at a Crossroads Global Report IAASTD.pdf. Accessed 4 Dec $201 \overline{3}$

Milder JC, Garbach K, DeClerck FAJ, Driscoll L, Montenegro M (2012) An assessment of the multifunctionality of agroecological intensification. A report prepared for the Bill and Melinda Gates Foundation, September 2012

Mueller ND, Gerber JS, Johnston M, Ray DK, Ramankutty N, Foley JA (2012) Closing yield gaps through nutrient and water management. Nature 490(7419):254-257. doi:10.1038/nature11420

Ochola D, Jogo W, Ocimati W, Rietveld A, Tinzaara W, Karamura DA, Karamura EB (2013) Farmers' awareness and perceived benefits of agro-ecological intensification practices in banana systems in Uganda. Afr J Biotechnol 12(29):4603-4613

Petersen B, Snapp S (2015) What is sustainable intensification? Views from experts. Land Use Policy 46:1-10. doi:10.1016/j.landusepol. 2015.02.002

Phalan B, Onial M, Balmford A, Green RE (2011) Reconciling food production and biodiversity conservation: land sharing and land sparing compared. Science 333(6047):1289-1291. doi:10.1126/ science. 1208742

Pretty JN (1997) The sustainable intensification of agriculture. Nat Res Forum 21(4):247-256 
Pretty JN (2008) Agricultural sustainability: concepts, principles and evidence. Philos Trans R Soc 363(1491):447-465. doi:10.1098/rstb. 2007.2163

Pretty JN, Thompson J, Hinchcliffe F (1996) Sustainable agriculture: impacts on food production and food security. International Institute for Environment and Development. Gatekeeper Series No. 60

Pretty JN, Toulmin C, Williams S (2011) Sustainable intensification in African agriculture. Int J Agric Sustain 9(1):5-24. doi:10.3763/ijas. 2010.0583

Raintree JB, Warner K (1986) Agroforestry pathways for the intensification of shifting cultivation. Agrofor Syst 4(1):39-54. doi:10.1007/ BF01834701

Reardon T, Clay D, Kangasniemi J (1998) Sustainable intensification in the highland tropics: Rwandan farmers' investments in land conservation and soil fertility. Econ Dev Cult Chang 46(2):351-377

Reardon T, Barrett C, Kelly V, Savadogo K (1999) Policy reforms and sustainable agricultural intensification in Africa. Dev Policy Rev 17(4):375-395. doi:10.1111/1467-7679.00093

Rosset PM, Martínez-Torres ME (2012) Rural social movements and agroecology: context, theory, and process. Ecol Soc 17(3):article 17 (online). doi:10.5751/ES-05000-170317

Royal Society London (2009) Reaping the benefits: science and the sustainable intensification of global agriculture. The Royal Society, London, 72 p

Ruben R, Lee DR (2000) Combining internal and external inputs for sustainable intensification No. 65. International Food Policy Research Institute (IFPRI)

Short JC, Broberg JC, Coglise CC, Brigham KH (2010) Construct validation using computer-aided text analysis (CATA). An illustration using entrepreneurial orientation. Organ Res Methods 13:320-347. doi:10.1177/1094428109335949

Staver C, Bustamante O, Siles P, Aguilar C, Quinde K, Castellón J, Somarriba F, Tapia A, Brenes S, Deras M, Matute N (2013) Intercropping bananas with coffee and trees: prototyping agroecological intensification by farmers and scientists. Acta Horticult (ISHS) 986:79-86

Struik PC, Kuyper TW, Brussard L, Leeuwis C (2014) Deconstructing and unpacking scientific controversies in intensification and sustainability: why the tensions in concepts and values? Curr Opin Environ Sustain 8:80-88. doi:10.1016/j.cosust.2014.10.002
Sumberg J (2002) The logic of fodder legumes in Africa. Food Policy 27(3):285-300. doi:10.1016/S0306-9192(02)00019-2

Tilman D, Balzer C, Hill J, Befort BL (2011) Global food demand and the sustainable intensification of agriculture. PNAS 108(50):20260 20264. doi:10.1073/pnas. 1116437108

Tittonell P (2014) Ecological intensification of agriculture - sustainable by nature. Curr Opin Environ Sustain 8:53-61. doi:10.1016/j.cosust. 2014.08.006

Tittonell P, Giller KE (2013) When yield gaps are poverty traps: the paradigm of ecological intensification in African smallholder agriculture. Field Crop Res 143:76-90. doi:10.1016/j.fcr.2012.10.007

Tscharntke T, Clough Y, Wanger TC, Jackson L, Motzke I, Perfecto I, Vandermeer J, Whitbread A (2012) Global food security, biodiversity conservation and the future of agricultural intensification. Biol Conserv 151(1):53-59. doi:10.1016/j.biocon.2012.01.068

USAID (2013). Feed the Future. Program for sustainable intensification. http://feedthefuture.gov/sites/default/files/resource/files/ftf factsheet_fsicsustainableint nov2013.pdf. Accessed June 2015

Van Bueren EM, van Bueren ETL, van der Zijpp AJ (2014) Understanding wicked problems and organized irresponsibility: changes for governing the sustainable intensification of chicken meat production. Curr Opin Environ Sustain 8:53-61. doi:10. 1016/j.cosust.2014.06.002

Vanlauwe B, Blomme G, van Asten P (2013a) Agro-ecological intensification of agricultural farming systems in the East and Central African Highlands. In: Vanlauwe B, van Asten P, Blomme G (eds) Agro-ecological intensification of agricultural systems in the African Highlands. Routledge, United Kingdom, pp 1-17

Vanlauwe B, van Asten P, Blomme G (eds) (2013b) Agro-ecological intensification of agricultural systems in the African Highlands. Routledge, United Kingdom, 314 p

Wezel A, Soldat V (2009) A quantitative and qualitative historical analysis of the scientific discipline agroecology. Int J Agric Sustain 7(1): 3-18. doi:10.3763/ijas.2009.0400

Wezel A, Bellon S, Doré T, Francis C, Vallod D, David C (2009) Agroecology as a science, a movement and a practice. A review. Agron Sustain Dev 29(4):503-515. doi:10.1051/agro/2009004

Wezel A, Casagrande M, Celette F, Vian JF, Ferrer A, Peigné J (2014) Agroecological practices for sustainable agriculture. A review. Agron Sustain Dev 34(1):1-20. doi:10.1007/s13593-013-0180-7 